Kanash O. Ye., Postgraduate Student Admiral Makarov National University of Shipbuilding Mykolaiv, Ukraine

DOI: DOI: https://doi.org/10.30525/978-9934-26-080-3-12

\title{
REVIEW OF DUAL EDUCATION FORMS PROJECTS IMPLEMENTATION IN UKRAINE
}

An official state statistics and analysis of academic practice studing, including the experience of cooperation between the higher educational institutions (HEIs) and business structures, clarified the state of dual education in Ukraine. Its identified forms used for the formation of professional competencies of students are systematized in Fig. 1. As we can see, the first thing that domestic HEIs proved to be capable of is to create conditions for students to master the relevant working professions. As for example, at the Admiral Makarov National University of Shipbuilding (NUOS) such a prospect opens up for those who study at the Mechanical Engineering Training and Research Institute (working profession - ship engineer) and at the Training and Research Institute of Automation and Electrical Engineering (ship electrician). At the Vinnytsia National Technical 48 
University - at the Faculty of Electrical Engineering and Electromechanics (locksmith-electrician).

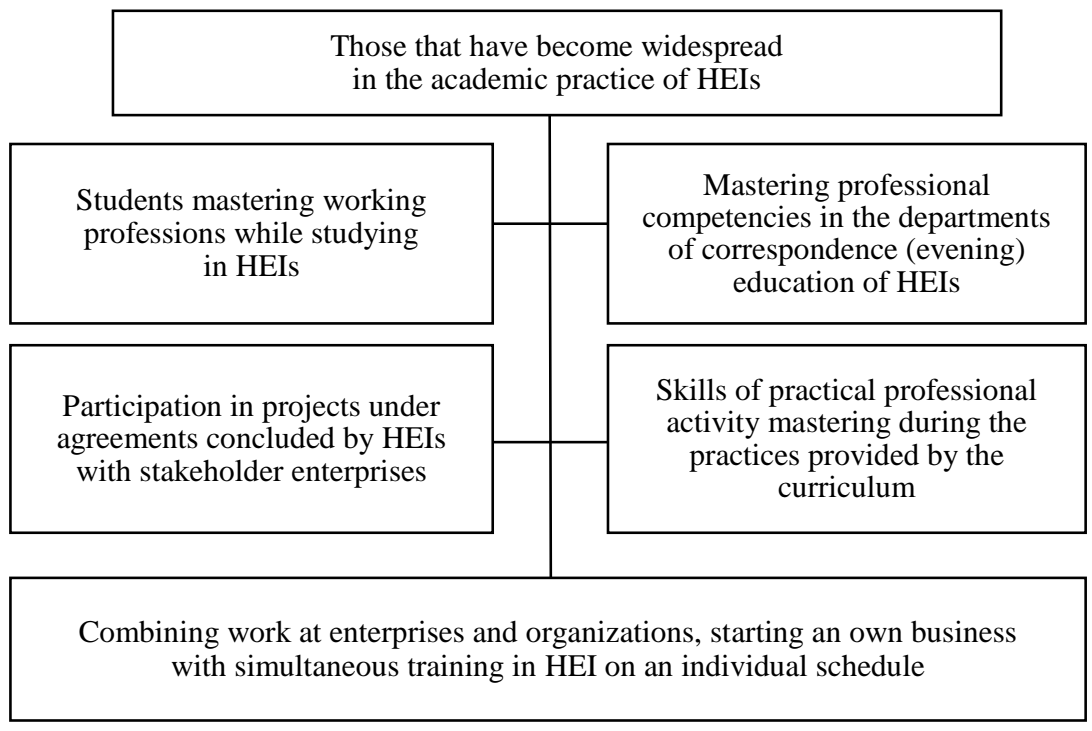

Figure 1. Current forms of duality of higher education in Ukraine

To understand the scale of the nationwide phenomenon, we turn to the information set out in table. 1. It accumulates information about graduates of all institutionally established in Ukraine higher education institutions (universities, academies, institutes of colleges, technical schools, colleges). First of all, we have to note an emerged positive trend - a share of those who mastered the working profession in the number of graduates who received referrals to work showed a clear upward trend. We see in this, though not explicit, but still an argument in favor of duality, as the acquisition of additional competencies has become a guarantee to graduates getting their first job in life. And this is a significant problem faced not only by young people of our country. 
The number of HEIs graduates who received referrals to work, persons

\begin{tabular}{|c|c|c|c|c|c|c|}
\hline \multirow{2}{*}{ Indicators } & \multicolumn{6}{|c|}{ Years } \\
\hline & \begin{tabular}{|l|l|}
2010 \\
\end{tabular} & 2014 & 2015 & 2016 & 2017 & 2018 \\
\hline $\begin{array}{c}\text { Number } \\
\text { of graduates, total }\end{array}$ & 654468 & 485195 & 447658 & 387727 & 420414 & 412843 \\
\hline $\begin{array}{l}\text { The number of graduates } \\
\text { who received a referral } \\
\text { to work, the total share } \\
\text { in the number of } \\
\text { graduates, } \%\end{array}$ & $\begin{array}{c}181942 \\
27,8\end{array}$ & $\begin{array}{c}134399 \\
27,7\end{array}$ & $\begin{array}{c}98037 \\
21,9\end{array}$ & $\begin{array}{c}68240 \\
17,6\end{array}$ & $\begin{array}{c}58858 \\
14,0\end{array}$ & $\begin{array}{c}49954 \\
12,1\end{array}$ \\
\hline $\begin{array}{l}\text { The number of graduates } \\
\text { who received a working } \\
\text { profession } \\
\text { simultaneously with the } \\
\text { educational and } \\
\text { qualification level, total }\end{array}$ & 48768 & 39006 & 30445 & 25297 & 24030 & 19409 \\
\hline $\begin{array}{l}\text { The share of those who } \\
\text { obtained the working } \\
\text { profession in the total } \\
\text { number of graduates, } \%\end{array}$ & 7.5 & 8.0 & 6.8 & 6,5 & 5,7 & 4,7 \\
\hline $\begin{array}{l}\text { The share of those who } \\
\text { have mastered the } \\
\text { working profession in } \\
\text { the number of graduates } \\
\text { who received referrals } \\
\text { to work, \% } \\
\text { Calculated index, \% }\end{array}$ & $\begin{array}{c}26,8 \\
100\end{array}$ & $\begin{array}{c}29,0 \\
108,1\end{array}$ & $\begin{array}{c}31,1 \\
116,0\end{array}$ & $\begin{array}{c}37,1 \\
138,4\end{array}$ & $\begin{array}{c}40,8 \\
152,2\end{array}$ & $\begin{array}{c}38,9 \\
150,8\end{array}$ \\
\hline
\end{tabular}

Source: developed by [1-4]

At the same time, we assert that from 2010 to 2018 simultaneously with the decline in the number of graduates (by 241.6 thousand people, which is $36.9 \%$ for the period that was analyzed) significantly decreased (up for now on 3.6 times) the number of those, who received referrals for such long-awaited work for them, after successful completion of training. The share of these lucky people from the total number of diploma holders at the end of 2018 was $12.2 \%$ or $15.7 \%$ less than in 2010 . 
We are convinced that this is happening for the reason that the state, unfortunately, has distanced itself and continues to increase the distance from the need to solve urgent problems that characterize the current state of higher education in Ukraine. The current and newly created bodies of central executive power, including in the field of quality assurance of educational services, focused mainly on formal comparison during the implementation of accreditation and licensing procedures of actual results of higher educational institutions academic and scientific activities with normative value of markers approved by officials of those bureaucratic institutions themselves.

At the same time, realizing the facts of life, we do not consider it fair to leave HEIs alone, at least with the problem of applying the principles of duality in the management of the educational process. This did not happen with vocational schools, maybe because they are concerned about the training of very scarce skilled workers, the lack of which is complained about by representatives of all Ukrainian industry branches.

Despite all the obstacles and difficulties, some higher education institutions demonstrate bright examples of the introduction of dual education elements through the establishment of cooperation with mutually beneficial business.

Among the typical examples of such cooperation we consider noteworthy, in particular, long-term fruitful cooperation of the Mykolaiv Territorial Administration (MTA) PrivatBank - one of the recognized leaders in education and further employment of students in Ukraine - with the Faculty of Marine Economics of Admiral Makarov National University of Shipbuilding. Its cooperation periodically updated and modernized and is built on the PrivatBank's project of «online practice for students» and principles of duality. [5].

Just as well as the previous example is the case of the well-known in Ukraine and abroad, the company «Marin Design Engineering Mykolaiv» (MDEM) [6]. The company developed a system of employer branding and recruitment of students to the team of MDEM employees, which in some cases led to a dual form of education. 
In the first and second cases different strategies were used, their content is determined by the specifics of each business: branched and built on intensive communications with customers (for PrivatBank) and highly specialized and involving specific hardware and software (in the MDEM case). Even the physical needs of employees are different: the number of staff of MTA PrivatBank as of 2019 was 22.5 thousand people, and in MDEM was 196 people.

Based on the information given in tab. 2 we can make several generalizations: first, the number of employed students indicates the successful implementation of projects; secondly, the dual education technologies chosen by the HEIs, employers and students, by definition, cannot be standard, unified. Each time, the developers of an educational and professional program, of course, if they are committed to the formal performance of their duties, must find the best possible solution. The criterion is a compliance of the organization of the educational process with the peculiarities of the future work of current students; thirdly, doing justice to initiatives of innovators and supporters of dual technologies, we see no reason to call the relevant activities comprehensive. This will continue to happen without: initiating changes to the content of education and schedules of the educational process with the addition of a production component, in accordance with the requests of employers and taking into account the requirements of state standards for certain specialties; introduction of block-modular construction of educational and professional programs curricula; creation of an institutional basis for cooperation between universities and goods producers, deprivation of last ones of consumer attitudes to the sources of intellectual capital, which need care and attention like any other source of useful resources; settlement of financial relations between the parties concerning the payment of salaries (to teachers when students are out of HEIs, to curators from business, who spend time on mentoring), scholarships and salaries to trainees; psychological support for career consulting of entrants and students of higher education institutions for the purpose of their professional self-determination. 


\section{Results of dual education projects implementation for the formation of human resources of enterprises}

\begin{tabular}{|c|c|c|c|c|c|c|}
\hline \multirow{2}{*}{ Enterprises } & \multicolumn{5}{|c|}{ The number of students who } \\
\cline { 2 - 7 } & \multicolumn{2}{|c|}{$\begin{array}{c}\text { participated in } \\
\text { dual projects }\end{array}$} & \multicolumn{2}{|c|}{$\begin{array}{c}\text { got a job during } \\
\text { their studentship }\end{array}$} & \multicolumn{2}{|c|}{$\begin{array}{c}\text { got a job after } \\
\text { graduation from } \\
\text { HEI }\end{array}$} \\
\cline { 2 - 7 } & persons & \%** & persons & \%** & persons & \%** \\
\hline $\begin{array}{c}\text { MTA } \\
\text { PrivatBank } *\end{array}$ & 3879 & 100.0 & 492 & 12.7 & 322 & 8.3 \\
\hline MDEM** & 36 & 100,0 & 15 & 41,7 & 21 & 58,3 \\
\hline
\end{tabular}

Explanation: total number since the beginning of the implementation of dual education programs (* since 2014 ; $* *$ since 2017 ); *** share of the total number of students who participated in dual education programs.

Analysis of other examples of mastering the practical activities skills, which can be attributed to forms of dual education, is a prospect for our further studies.

\section{References:}

1. Ishchenko A.Yu. (2014) Global trends and problems of education development: consequences for Ukraine. Analytical note. National Institute for Strategic Studies. URL: http://www.euroosvita.net/prog/print.php/prog/print.php? $\mathrm{id}=3288$.

2. Repko M. (2016) Expensive and bad, but for everyone: how much does higher education really cost for Ukraine?. URL: https://voxukraine.org/uk/education-ua/.

3. Licensing conditions for educational activities. In the wording of the resolution of the Cabinet of Ministers of Ukraine № 347 from 10.05.2018. URL: https://zakon.rada.gov.ua/laws/show/1187-2015-\%D0\%BF.

4. Higher education in Ukraine in 2018. Statistical bulletin. State Statistics Service, Kyiv. 2019. URL: http://www.ukrstat.gov.ua/operativ/operativ2005/osv_rik/ osv_u/vysh_osvita/arch_vysh_osvita.htm.

5. Online practice in PrivatBank. URL: https://practice.privatbank.ua.

6. Marine Design Engineering Mykolayiv. URL: https://www.damen.com/ en/companies/marine-design-engineering-mykolayiv. 